\title{
PANKREAS EKTOPIK DI SUBMUKOSA ILEUM PADA PENDERITA ADENOKARSINOMA KOLON
}

\author{
Poppy M. Lintong \\ Eddy H. Tambajong
}

\begin{abstract}
Bagian Patologi Anatomi Fakultas Kedokteran Universitas Sam Ratulangi Manado
Email: magda_plin@yahoo.com
\end{abstract}

\begin{abstract}
Ectopic pancreatic tissue is a rarely found congenital anomaly. In routine autopsies, it has been found at about $2 \%$. In this case, ectopic pancreatic tissues are found in the stomach, duodenum, jejunum, appendix, Meckel diverticulum, and more rarely in the ileum. Ectopic pancreas is mostly asymptomatic and occasionally found without any pre-operative suspicion. Microscopically, this ectopic tissue mostly consists of acini and gland ducts; albeit Langerhans islets were found in $1 / 3$ of the cases. We reported a 57-year-old male, with a pain in the abdomen and an intestinal obstruction due to a sigmoid tumor. In laparatomy, there was a tumor mass in the sigmoid colon and a nodule (diameter $1.5 \mathrm{~cm}$ ) in the submucosal layer of the ileum. In the histopathological examination, we identified that these ileum nodal tissues contained acini and pancreatic gland ducts, and the tumor mass of the sigmoid colon showed a papillary adenocarcinoma. At first, this submucosal nodule was diagnosed as a carcinoid tumor, but based on the immunohistochemical examination at the Diagnostic Centre of the Pathology Department, University of Indonesia, the nodule tissue, stained with chromogranin, showed a negative result. It means that the diagnosis of a carcinoid tumor was eliminated.
\end{abstract}

Keywords: exocrine glands, pancreatic gland ducts, submucosal layer of ileum.

\begin{abstract}
Abstrak: Jaringan pankreas ektopik merupakan kelainan kongenital dan jarang ditemukan. Insidennya sekitar $2 \%$ dari pemeriksaan otopsi rutin. Tempat tersering ditemukan pankreas ektopik yaitu pada lambung, duodenum, jejunum, apendiks, divertikulum Meckel, dan lebih jarang pada ileum. Pankreas ektopik sering asimtomatik, kadang ditemukan dan tanpa kecurigaan pada saat preoperatif. Gambaran mikroskopik jaringan pankreas ektopik umumnya terdiri dari asinus dan duktus kelenjar, sedangkan pulau-pulau Langerhans hanya ditemukan pada 1/3 kasus. Kami melaporkan kasus seorang laki-laki berusia 57 tahun dengan gejala nyeri perut dan obstruksi usus yang disebabkan tumor kolon sigmoid. Pada saat laparatomi, selain massa tumor pada kolon sigmoid juga ditemukan nodul berdiameter $1,5 \mathrm{~cm}$ pada submukosa ileum. Pada pemeriksaan histopatologi, jaringan dari nodul submukosa ileum menunjukkan asinus-asinus dan duktus duktus kelenjar pankreas di antara stroma submukosa ileum, sedangkan massa tumor pada kolon sigmoid menunjukkan adenokarsinoma papiler. Pada awalnya nodul submukosa pada ileum dibuat diagnosis sebagai carcinoid tumor, namun berdasarkan pemeriksaan imunohistokimia di Sentra Diagnostik Departement Patologi Anatomik FK UI yang memberi hasil pulasan kromogranin negatif, maka diagnosis carcinoid tumor telah disingkirkan.
\end{abstract}

Kata kunci: kelenjar eksokrin, duktus kelenjar pankreas, lapisan submukosa ileum

Pankreas aberan, asesori, heterotropik, atau ektopik adalah jaringan pankreas normal yang berada di luar dari pankreas dan tidak berhubungan dengan jaringan pankreas normal, baik secara anatomis maupun suplai darah. ${ }^{1}$

Pankreas ektopik merupakan kelainan kongenital yang jarang ditemukan. ${ }^{2,3}$ Insi- 
dennya sekitar $2 \%$ pada pemeriksaan otopsi rutin dan ditemukan secara insidentil, ${ }^{4,5}$ walaupun ada yang melaporkan insidennya berkisar $1-15 \% .{ }^{1}$ Tempat tersering ditemukan pankreas ektopik yaitu saluran pencernaan $^{1-5}$ terutama duodenum, lambung, ${ }^{2}$ jejunum, divertikelum Meckel, ileum, apendiks, kolon dan omentum; juga pada duktus biliaris dan kantong empedu. Jarang-jarang dapat juga ditemukan pankreas ektopik pada paru-paru dan umbilikus. ${ }^{1} \mathrm{~Pa}-$ da satu kasus dilaporkan terdapatnya pankreas ektopik pada daerah peri-pankreatik dan hilus limpa. ${ }^{6}$ Pankreas ektopik ditemukan pada kisaran usia dari beberapa hari sampai 84 tahun. Kasus kasus yang telah dilaporkan pernah terjadi antara lain pada laki-laki berusia 59 tahun, ${ }^{7}$ bayi laki-laki 6 bulan, ${ }^{8}$ dan perempuan 85 tahun. ${ }^{9}$

Patogenesis terjadinya pankreas ektopik belum jelas, namun diduga adanya sisasisa embrionik bagian ventral bud yang atrofik, migrasi aberan dari sisa-sisa ventral bud, metaplasia dari sel-sel endodermal multipoten, dan yang pada duodenum berasal dari metaplasia kelenjar-kelenjar Brunner. ${ }^{1}$

Secara makroskopik pankreas ektopik berbentuk nodul diameter $0,2-5 \mathrm{~cm}$ yang umumnya terletak di submukosa. ${ }^{1}$ Pernah dilaporkan satu kasus dengan nodul ekstramural pada ileum. ${ }^{7}$ Nodul submukosa yang besar dapat disertai umbilikasi, atau dengan orifisium duktus sentral. ${ }^{1,3}$ Gambaran mikroskopik jaringan pankreas ektopik umumnya terdiri dari arsitektur lobuler pankreas normal dengan asinus-asinus dan duktus kelenjar, ${ }^{1,2}$ dan kadang-kadang terdapat pulau-pulau Langerhans. ${ }^{5}$ Pulau Langerhans hanya ditemukan pada $1 / 3 \mathrm{ka}-$ sus dan dapat mengandung keempat jenis sel endokrin, namun yang terbanyak ialah sel-sel alfa sedangkan sel-sel polipeptida pankreatik (PP) hanya sedikit. $^{3}$

Jaringan pankreas ektopik dapat berfungsi aktif dan menyekresi hormon. Setiap perubahan patologik yang terjadi pada kelenjar pankreas normal dapat juga terjadi pada jaringan pankreas ektopik ${ }^{1,3}$ termasuk pankreatitis akut (sudah dilaporkan terjadi pada seorang perempuan berusia 85 ta- hun ${ }^{9}$ ), dan neoplasma dari eksokrin dan endokrin pankreas. ${ }^{3}$ Kira-kira $2 \%$ dari neoplasma pulau-pulau Langerhans timbul pada jaringan pankreas ektopik. ${ }^{5}$ Transformasi ganas pada jaringan pankreas ektopik jarang terjadi. ${ }^{1}$ Jaringan pankreas ektopik pada lambung dapat menyebabkan perdarahan, ulserasi, atau obstruksi pilori. Bila jaringan ektopik ini terletak pada ampula Vateri, dapat menyebabkan ikterus obstruktif, ${ }^{3}$ obstruksi bilier dan kolesistitis. ${ }^{1}$ Sebagian besar kasus pankreas ektopik asimtomatik dan ditemukan secara insidentil pada waktu otopsi atau pembedahan. Pankreas ektopik pada ileum juga sering asimtomatik, dan kadang-kadang menyebabkan intususepsi. ${ }^{8,10}$

Dewasa ini ultrasonografi endoskopi telah digunakan secara luas untuk mendiagnosis penyakit saluran cerna, terutama lesi-lesi sub-mukosa. Endosonografi dapat menunjukkan perbedaan ekogenik antara jenis-jenis tumor submukosa dan kedalaman invasinya. Konfirmasi histologik masih diperlukan untuk suatu diagnosis pasti. ${ }^{11}$

\section{LAPORAN KASUS}

Seorang laki-laki berusia 57 tahun dengan gejala klinis nyeri perut, tidak bisa buang air besar, dan muntah-muntah. Diagnosis klinik yang ditegakkan ialah obstruksi usus mekanik karena tumor kolon sigmoid. Pada saat intraoperatif, selain massa tumor pada kolon sigmoid $(3 \times 3 \times 2 \mathrm{~cm})$, juga ditemukan nodul pada submukosa ileum (diameter $1,5 \mathrm{~cm}$ ). Setelah pembedahan, dilakukan pemeriksaan histopatologik jaringan ileum dan kolon sigmoid di Pusat Diagnostik Patologi Anatomi Manado. Hasil pemeriksaan histopatologik tersebut menunjukkan jaringan makroskopik ileum dengan panjang $5 \mathrm{~cm}$ dan ukuran diameter 2 $\mathrm{cm}$; pada irisan tampak nodul berukuran $1,5 \mathrm{~cm}$, berwarna putih kekuningan terletak pada submukosa (Gambar 1). Kolon sigmoid berukuran $14 \times 9 \times 4 \mathrm{~cm}$. Pada irisan sigmoid terlihat mukosa usus besar sebagian dengan rugae yang masih utuh, dan pada bagian tengah terdapat massa tumor dengan ukuran diameter $3 \mathrm{~cm}$ warna putih keabu- 
abuan. (Gambar 2). Hasil pemeriksaan mikroskopik dari usus halus menunjukkan dinding usus halus dengan lapisan mukosa beserta kelenjar mukosa, dan pada submukosa tampak jaringan pankreas terdiri dari asinus-asinus dan duktus kelenjar pankreas. (Gambar 3, 4). Gambaran usus besar menunjukkan dinding usus besar dengan lapisan mukosa beserta kelenjar mukosa, $\mathrm{Pa}-$ da lapisan muskularis tampak bangunanbangunan kelenjar dan papiler yang dilapisi sel-sel epitel torak berinti hiperkromatik dan sel-sel epitel berlapis, yang telah invasif secara luas sampai lapisan serosa. (Gambar 5, 6). Pemeriksaan imunohistokimia di Departemen Patologi Anatomi Sentra Diagnostik Patologi memberi hasil negatif untuk pulasan kromogranin nodul pada usus halus.

\section{BAHASAN}

Jaringan pankreas ektopik pada usus halus ileum termasuk kelainan kongenital yang jarang. ${ }^{3}$ Jaringan pankreas ektopik lebih sering berlokasi pada duodenum, lambung bagian antrum, dan jejunum; juga pada esofagus, paru-paru, mesenterium, limpa, kantong empedu, duktus biliaris dan divertikulum Meckel. ${ }^{12,13}$ Pada kasus ini kelenjar pankreas ektopik berbentuk nodul, berbatas jelas, warna kekuningan, diameter $2 \mathrm{~cm}$, terletak pada submukosa ileum (Gambar 1). Pustaka acuan menyebutkan bahwa gambaran makroskopik nodul pankreas ektopik biasanya berbatas jelas, berwarna kuning, padat, berlobi, berukuran diameter $0,2-5 \mathrm{~cm}$, dan terbanyak pada submukosa; oleh karena itu perlu dibuat diagnosis banding dengan nodul submukosa pada saluran cerna. ${ }^{1}$

Nodul submukosa di ileum pada kasus ini menyerupai nodul submukosa carcinoid tumor. Carcinoid tumor paling sering berlokasi di ileum, biasanya ber-bentuk nodul polipoid di submukosa, warna kuning kecoklatan, ukuran kecil $(2,5-3 \mathrm{~cm})$ dan biasanya ditemukan insidentil. Gejala simtomatik muncul sekunder terhadap sekresi hormon. ${ }^{1,14,15}$

Gambaran mikroskopik carcinoid tumor terdiri dari struktur asiner yang dilapisi sel-sel uniform berbentuk bulat dengan inti hiperkromatik. Sel-sel tersusun dalam struktur kelenjar/ asiner, sarangsarang, dan trabekel yang dipisahkan oleh stroma fibrotik. ${ }^{1,14}$ Struktur asiner pada carcinoid tumor kadang-kadang mirip dengan struktur asiner kelenjar pankreas. Secara mikroskopik jaringan pankreas ektopik sama dengan arsitektur lobuler pankreas normal dan terdiri dari asinus dan duktus kelenjar; dan lebih dari $84 \%$ kasus mengandung pulau Langerhans. ${ }^{3}$ Pada kasus ini hanya ditemukan asinus dan duktus kelenjar pankreas tanpa pulau-pulau Langerhans; sama halnya dengan laporan kasus pankreas ektopik pada ileum yang disertai gejala intususepsi. ${ }^{8}$ Pustaka acuan lainnya menyebutkan hanya $1 / 3$ kasus pankreas ektopik terdiri dari pulau-pulau Langerhans, selain duktus dan asinus kelenjar pankreas. ${ }^{3}$

Awalnya kasus ini didiagnosis sebagai carcinoid tumor, namun pemeriksaan imunohistokimia pulasan kromogranin memberi hasil negatif; dengan demikian diagnosis carcinoid tumor telah disingkirkan.

Pankreas ektopik pada ileum yang terdapat bersama-sama penyakit lain sudah pernah dilaporkan, sebagai contoh dengan lipoma dan fibromatosis. ${ }^{16}$ Kasus yang kami laporkan merupakan hal yang sangat jarang yaitu terdapatnya jaringan pankreas ektopik pada penderita adenokarsinoma papiler kolon sigmoid. Tidak terdapat hubungan antara kejadian adenokarsinoma kolon dan jaringan pankreas ektopik pada ileum. Penyebab pasti terjadinya adenokarsinoma bentuk papiler pada kasus ini belum diketahui. Yang berisiko tinggi menderita adenokarsinoma kolon atau karsinoma kolorektal ialah penderita dengan riwayat keluarga kanker herediter nonpoliposis, kanker kolon, familial adenomatous polyposis syndromes, kolitis ulseratif, Crohn disease, atau bentuk-bentuk kolitis infeksiosa. ${ }^{15}$ Pada kasus ini nodul submukosa di ileum (yang ternyata merupakan jaringan pankreas) hanya ditemukan secara insidentil saat operasi tumor kolon sigmoid; hal ini tidak dicurigai pada saat preoperatif. 
Beberapa teori yang menerangkan terjadinya jaringan pankreas ektopik umumnya menyetujui bahwa pankreas ektopik terbentuk antenatal, namun mekanisme pasti terjadinya hal ini belum jelas.
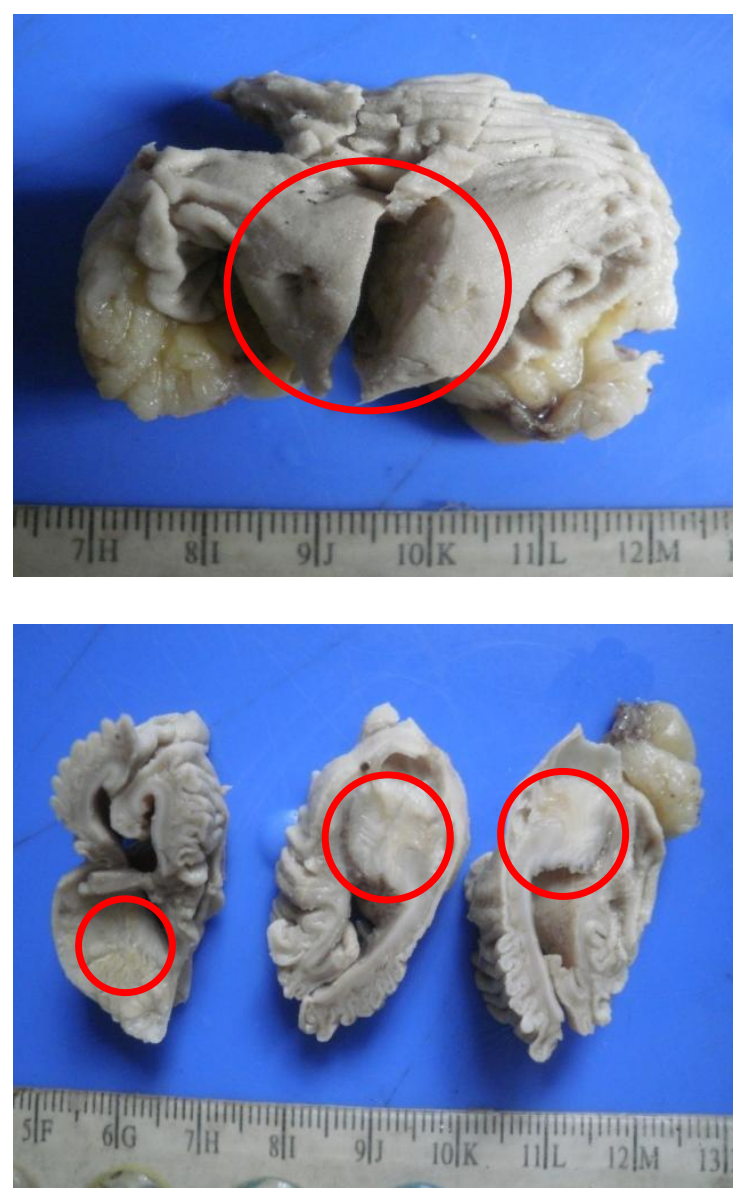

Gambar 1. Gambar makroskopik ileum dengan nodul di submukosa berdiameter $1,5 \mathrm{~cm}$.

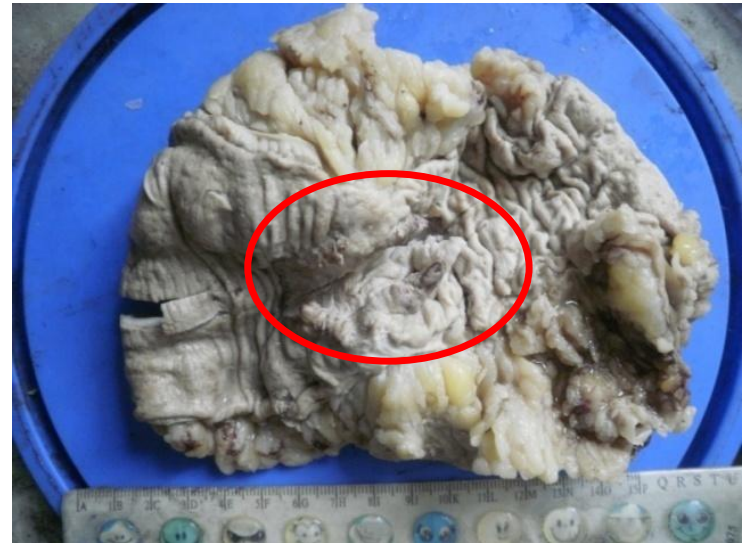

Gambar 2. Gambar mikroskopik usus besar dengan massa tumor berdiameter $3 \mathrm{~cm}$ warna putih keabu-abuan
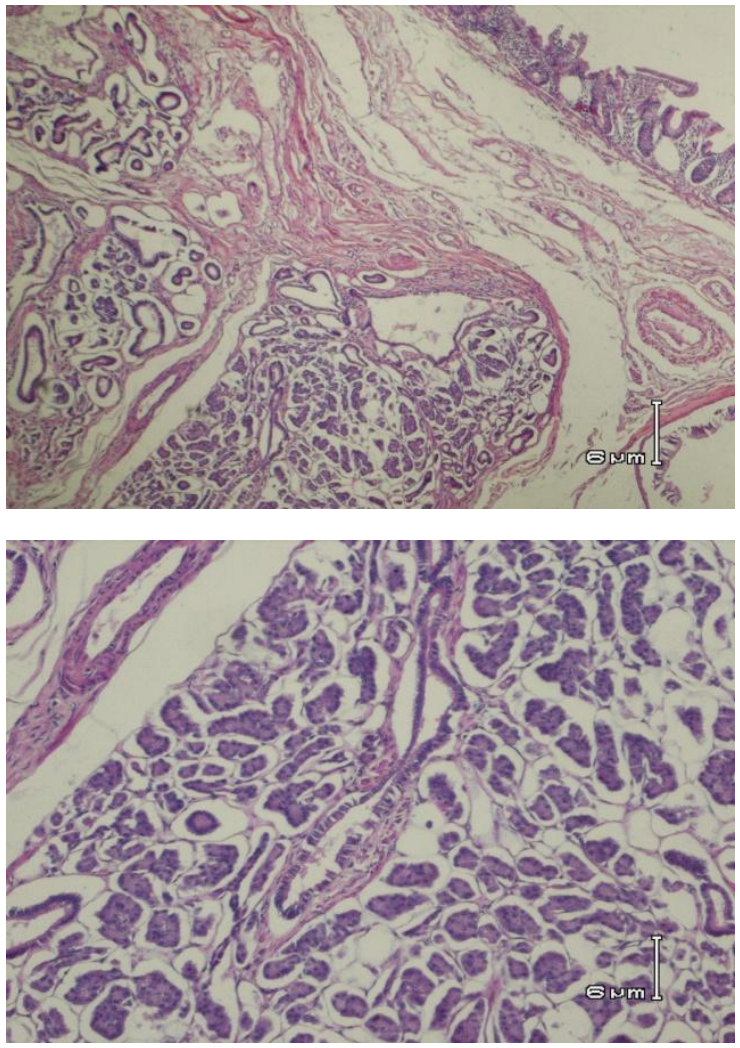

Gambar 3. Jaringan pankreas pada submukosa ileum, terdiri dari asinus-asinus dan duktus kelenjar yang melebar $(40 \mathrm{x}$ dan $100 \mathrm{x})$
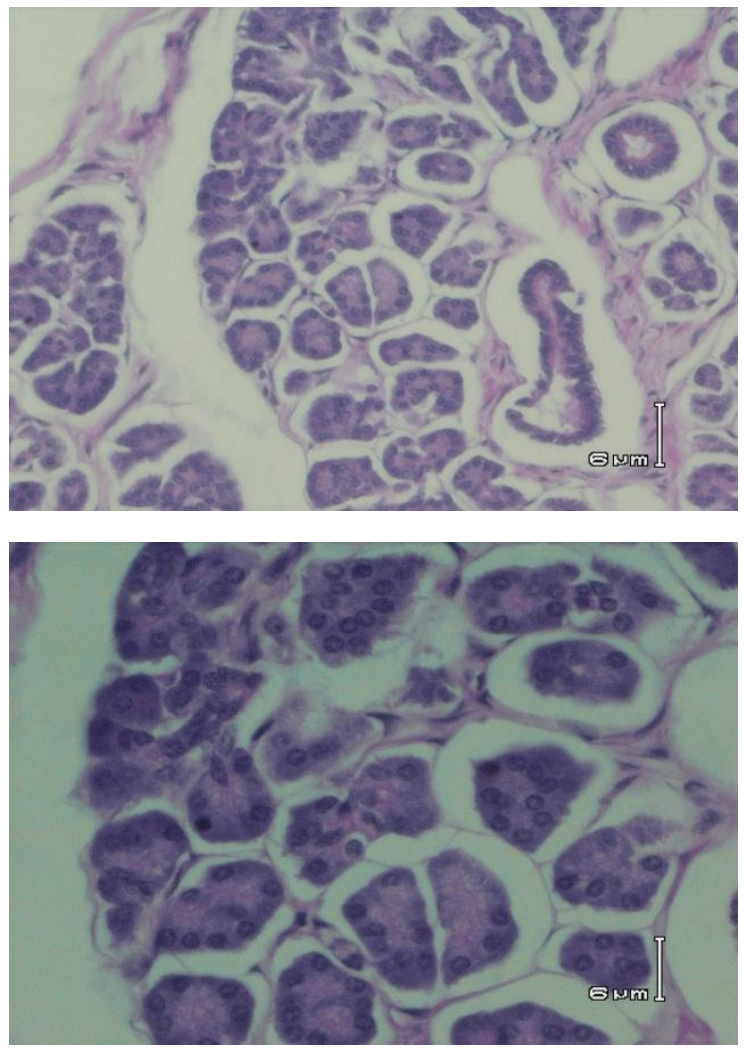

Gambar 4. Jaringan pankreas pada submukosa ileum, terdiri dari asinus dan duktus kelenjar (200x dan 400x). 

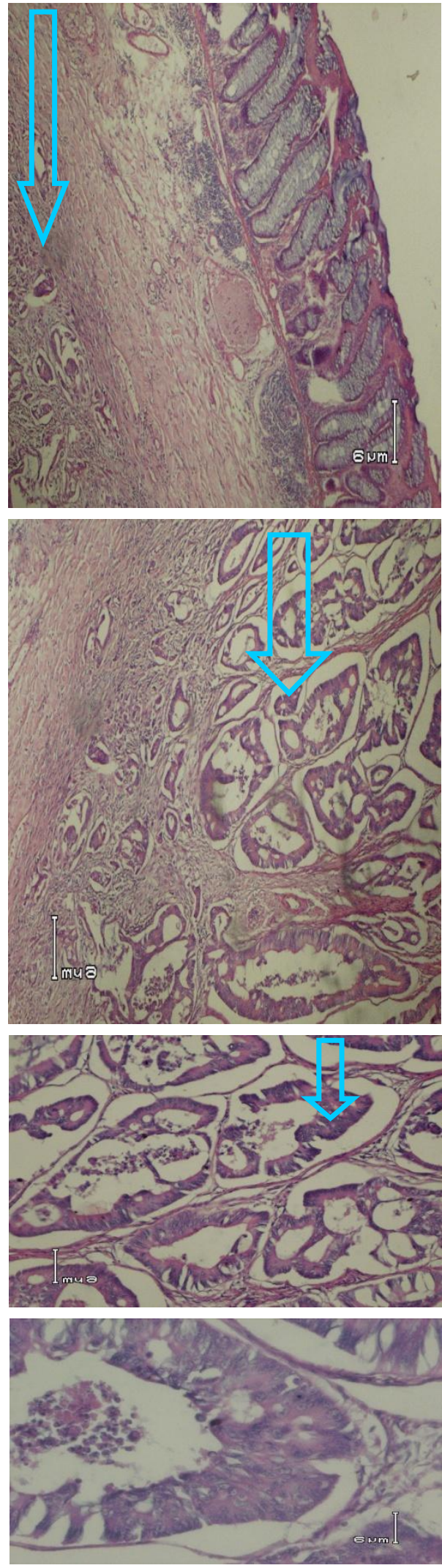

Gambar 5. Jaringan usus besar dilapisi mukosa. Pada lapisan muskularis terdapat bangunanbangunan kelenjar, tersusun oleh sel-sel epitel torak dengan inti hiperkromatik yang tersusun berlapis-lapis. (pembesaran $40 \mathrm{x}, 100 \mathrm{x}, 200 \mathrm{x}$, 400x).
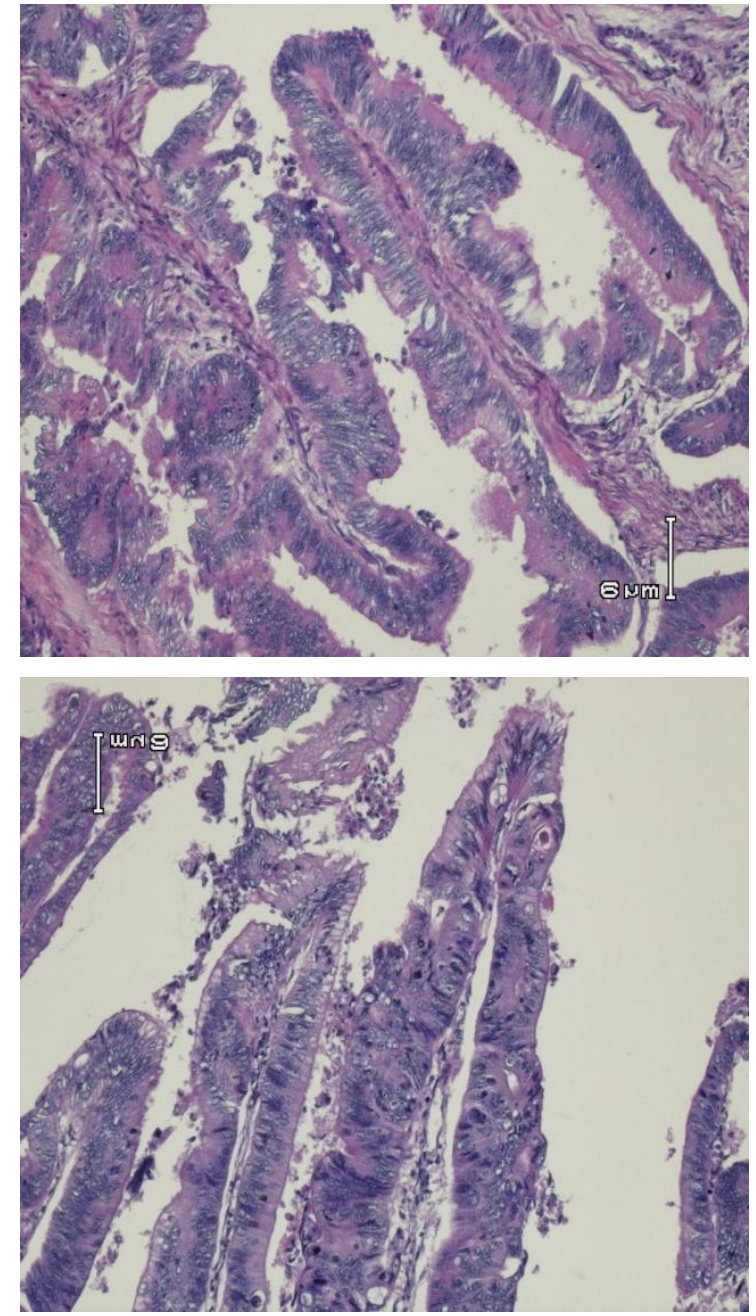

Gambar 6. Jaringan usus besar dengan sel-sel tumor tersusun pola papiler (pembesaran 200x).

Menurut Horgan, ${ }^{17}$ sebelum terjadi penyatuan, tonjolan-tonjolan kecil dari ujungujung percabangan benih pankreas anterior dan posterior mengadakan perlekatan ke dinding usus pada berbagai lokasi, yang disertai kelenjar dari usus dengan pola pertumbuhan dan perkembangan normal. Pemindahan tonjolan-tonjolan ini menetap pada lokasi baru di dinding usus. Warthin, ${ }^{17}$ mengusulkan bahwa jaringan pankreas ektopik berkembang dari tonjolan lateral duktus pankreas rudimenter, kemudian berpenetrasi ke dinding usus. Selanjutnya massa jaringan pankreas terperangkap dan ditranspor ke atas atau ke bawah dengan pertumbuhan longitudinal di dalam saluran cerna. ${ }^{17}$

Gejala nyeri perut yang dialami pada kasus ini bersifat akut. Terjadinya nyeri 
perut disebabkan oleh adanya obstruksi karsinoma kolon. Pada penderita karsinoma kolorektal kira-kira 50\% kasus mengeluh nyeri perut, yang sering terjadi pada penderita karsinoma kolorektal dengan invasi tumor sampai ke lapisan serosa. ${ }^{15}$ Pada kasus ini secara histopatologik terlihat selsel tumor telah menembus lapisan muskularis eksterna sampai ke serosa kolon sigmoid. Kelenjar pankreas ektopik di submukosa ileum tidak memberikan gejala (asimtomatik), dan hanya ditemukan pada saat laparatomi.

\section{SIMPULAN}

Telah dilaporkan kasus pankreas ektopik di submukosa ileum pada penderita adenokarsinoma kolon. Kasus ini jarang ditemukan, hanya insidentil pada saat pembedahan tumor kolon sigmoid. Awalnya nodul pada submukosa ileum diduga sebagai carcinoid tumor, namun dengan pemeriksaan imunohistokimia diagnosis carcinoid tumor dapat disingkirkan.

Penanganan medis yang modern dengan bermacam-macam metode diagnostik seperti pemeriksaan endoskopi dan ultrasonografi dapat mendiagnosis lesi atau tumor submukosa pada saluran cerna, namun diagnosis pasti suatu jaringan pankreas ektopik hanya dapat ditegakkan berdasarkan pemeriksaan histopatologi.

\section{DAFTAR PUSTAKA}

1. Centeno BA. Diagnostic cytology of the pancreas and biliary tract. In: Odze RD, Goldblum JR, Crawford JM, editors. Surgical Pathology of the GI Tract, Liver, Biliary Tract, and Pancreas Volume 1. Philadelphia: Elsevier, 2009; p. 600-1.

2. Strutynska-Marta K, Miroslaw N, Markowska-Alicja W, BudrewiczKatarzyna C. Heterotropic pancreas. In: Chirurgiczn PP, editor. The Stomach (Type II According To Heinrich)- Literature Review and Case Report. 2011;83(3):171-4.

3. Rosai J. Rosai and Ackerman's Surgical
Pathology Volume 1 (Ninth Edition). London: Mosby, 2004; p.810-22, 1063.

4. Chandrasoma P, Clive TR. Concise Pathology (Third Edition). Stamford: Appleton \& Lange, 1998; p.671.

5. Ralph HH, Iacobuzio-Christine D. The pancreas. In: Kumar V, Abbas Abul K, Nelson F, Jon AC, editors. Robbins and Cotran Pathologic Basis of Disease (Eight Edition). Philadelphia: Elsevier Saunders, 2010; p.891-93.

6. Kirti G, Vasishra RK. Ectopic pancreatic islet in splenic hilum and peripancreatic fat. Diagnostic pathology [homepage on the internet]. 2008 [cited 2010 Mar]. Available from: 3:3doi:10.1186/1746-1596-3-3.

7. Naotake H, Yasuhiro S, Motoo T, Kazuaki H, Taro K, Yoshiyuki M. A case of extramurally growing ectopic pancreas. in the ileum in an adult. Journal of Japan Surgical Association [serial online]. 2005 [cited 2010 Mar]; 66(12):30493052. Available from: http://sciencelinks.jp/jeast/display.p hp ?id=000020060706A0036561

8. Shin HO, Lee SW, Heasoo K, Young HJ. Isolated heterotropic pancreas in ileo-ileal intussusception. Seoul: Department of Radiology and Pathology Ewha Womans University, 2009; p.158-710.

9. Benbow EW. Simultaneous acute inflammation in entopic and ectopic pancreas. J.Clin Pathol. 1988;41:430-434.

10. Hamada Y, Yonekura Y, Tanano A. Isolated heterotropic pancreas causing intussuception. Eur J Pediatr Surg. 2000;10:197-200

11. Zinkkiewics $\mathrm{K}$, Juskiewicz W, Zgodzinski, Justyna S, Grzegorz C, Jaroslaw F, et al. Ectopic pancreas: endoscopic, ultrasound, and radio-logical features. Folio Morphol. 2003;62(3):p.205-209.

12. Hazzan D, Peer G, Shiloni E. Symptomatic pancreas of stomach. Isr Med Assoc J. 2002;4:388-89.

13. Arkuszewski P, Holynski J, Mussur 
M. A symptomatic ectopic pancreas in the stomach - a case report. Pol Merkur Lekarski; 2009;26:483-95.

14. Robert OD, Amy NE. Neoplastic diseases of the small and large intestines. In: Steven SG, Ronald DA, William FJ, Virginia LA, Mark WR, editors. Silverberg's Principles and Practice of Surgical Pathology and Cytopathology Volume 2 (Fourth Edition). Philadelphia: Churchill Livingstone Elsevier, 2006; p.1425-41.

15. Fenoglio-Cecilia PM, Amy NE, Grant SN, Patrick LE, Peter IG. Gastrointestinal Pathology (Third Edition). Philadelphia: Lippincott Williams \&
Wilkins Wolter Kluwer, 2008.

16. Fikatas P, Sauer IM, Mogi M, Menenakos C, Luegering A, Schumacher G et al. Heterotropic ileal pancreas with lipoma and coexisting fibromatosis associated with a rare case of gastrointestinal bleeding. A case report and review of the literature. JOP. 2008;9(5):640-3.

17. Barbosa JdeC, Dockerty MB, Waugh JM. Pancreatic heterotropia: review of the literature and report of 41 authenticated surgical cases, of which 25 were clinically significant. Surg Gynecol Obstet. 1946;82:527-42. 